\title{
Uji Maqashid Syariah Perbankan Syariah Di Indonesia
}

\author{
Mahmudatus Sa'diyah' ${ }^{1)}$, Asep Gugun Gumilar ${ }^{2)}$, Edi Susilo ${ }^{3 *}$ \\ ${ }^{1,2,3}$ Fakultas Ekonomi dan Bisnis, Universitas Islam Nahdlatul Ulama Jepara \\ *Email korespondensi: edisusilo@ unisnu.ac.id
}

\begin{abstract}
The purpose of this study is to examine the performance of Islamic banking in Indonesia based on MSI (Maqashid Shariah Index). Combining the maqashid sharia Ibn Ashur and Abu Zaharah with the methodological concept developed by Sekaran (Mohammed et al., 2015). The three objectives of Maqashid Sharia: (1) Tahdhib al-Fard (Educating individuals); (2) Iqamah al- 'Adl (establishing justice); and (3) Jalb al-Maslahah (Public Interest). Simple Additive Weighting (SAW) is used as a method for ranking the performance of Islamic banking based on the final results from MSI. The results showed 14 Islamic Commercial Banks (BUS) in 2011-2019, had an average IMS 0.1694. The IMS of five Islamic banks is below the average, namely BMS, Maybank, BTPNS, BAS, and BNTBS. IMS first rank is BPS index 0.2336, second rank is BVS index 0.2168, third rank is BSB index 0.2164, fourth rank is BCAS with index 0.2129, fifth rank is BMI with 0.183 index, sixth rank is BSM with an index of 0.1895, the seventh rank is BRIS with an index of 0.1904, the eighth is BNIS with an index of 0.1814, the ninth is BJBS 0.1759, the tenth is BMS 0.153, the eleventh is Maybank index 0.1289, the twelfth is BTPNS 0.1237 the thirteenth is BAS 0.0930, and the last fourteen is BNTBS with an index of 0.1289
\end{abstract}

Keyword: Maqashid Syariah, Perbankan Syariah

Saran sitasi: Sa'diyah, M., Gumilar, A. G., \& Susilo, E. (2021). Uji Maqashid Syariah Perbankan Syariah Di Indonesia. Jurnal Ilmiah Ekonomi Islam, 7(01), 373-385. doi: http://dx.doi.org/10.29040/jiei.v7i1.1725

DOI: http://dx.doi.org/10.29040/jiei.v7i1.1725

\section{PENDAHULUAN}

Kehadiran Bank Syariah di Indonesia pada awal 1990-an, tepatnya pada tahun 1992, dengan kehadiran Bank Muamalat Indonesia (BMI) sebagai Bank Syariah pertama di Indonesia. Setelah keluarnya undang-undang No. 10 tahun 1998 tentang Perbankan, kemudian diikuti oleh lahirnya UU No. 21 tahun 2008 tentang Perbankan Syariah, keberadaan Bank Syariah mulai tumbuh dan berkembang secara signifikan. Data Statistik Perbankan Syariah (SPS) per 31 Desember 2018 yang diterbitkan oleh OJK; saat ini terdapat 14 Bank umum Syariah , 19 unit usaha Syariah dan 167 BPRS di seluruh Indonesia yang didukung oleh 1.875 kantor jaringan Bank Umum Syariah, 354 jaringan kantor unit usaha Syariah. Total asset Bank Syariah per Des 2018 sebesar 328.338 milliar rupiah. Pertumbuhan Bank Syariah juga menunjukkan angka yang menggembirakan dibandingkan dengan pertumbuhan Bank konvensional. Bank Syariah tumbuh rata-rata $43,16 \%$, sedangkan Bank konvensional hanya tumbuh sebesar $12,4 \%$.
Pertumbuhan perbankan syariah baik secara nasional maupun global diikuti oleh pertumbuhan sektor lain, seperti produk halal dan lifestyle syariah yang saat ini sedang marak di berbagai Negara. The State of the Global Islamic Economy Report 2018/2019 mencatat bahwa konsumsi halal dunia pada tahun 2017 mencapai USD 2,1 triliun, dan akan mengalamai pertumbuhan seiring dengan meningkatnya jumlah penduduk muslim dunia, yang saat ini 1,84 miliar jiwa, akan tumbuh $27,7 \%$ dari total populasi dunia pada tahun 2030 (Indonesian Ministry of National Development Planning, 2019). Data tersebut menjadi potensi bagi dunia perbankan untuk melakukan ekspansi dalam pelayanan pada sector riil yang sedang tumbuh pesat.

Pertumbuhan perbankan syariah perlu diikuti perbaikan kinerja keuangan maupun kinerja non keuangannya. Secara regulatif, kinerja perbankan dan perbankan syariah diatur dalam PBI No 6/10/PBI/2004, tentang kinerja CAMELS (Capital, Asset, Management, Earning, Liquidity, Sensitivity of 
Market Risk), selain itu PBI No.13/1/PBI/2011 mengatur penilaian kinerja bank dengan pendekatan RGEC (Risk Profile, Good Corporate Governance, Earning, dan Capital), pendekatn lain adalah metode EVA (Economic Value Added) (Rahman et al., 2016). Bank syariah sesuai tujuannya untuk kesejahteraan dan kemaslahatan kehidupan, baik lahir maupun batin, dunia dan ahirat serta mencapai falah yang ukurannya tidak dapat diukur semata-mata dari ukuran keuangan (Muhammad et al., 2020). Kritik terhadap bank syariah atas ukuran kinerja terutama karena tujuan dasar perbankan syariah sampai saat ini belum tertangani secara serius, sehingga focusnya masih berkutat seputar kinerja keuangan (Nasuka, 2017). Maka dari itu gagasan para cendekian muslim untuk mengukur kinerja perbankan syariah berdasarkan maqashid syariah telah disambut baik, terutama di dunia akademik, namun belum terimplementasi secara regulative oleh otoritas perbankan di berbagai Negara (Mohammed \& Razak, 2008).

Penelitian terdahulu kinerja keuangan perbankan syariah telah banyak dilakukan. Seperti: tingkat kesehatan Bank BNI Syari'ah dengan menggunakan metode CAMELS menunjukkan Sangat Sehat, sedangkan dengan menggunakan metode RGEC ratarata menunjukkan predikat Sehat (Hafiz, 2018). Rasio CAMEL berpengaruh pada kesehatan di BTN Syariah (Novyanti \& Roestiono, 2014), bank syariah di Indonesia memiliki tingkat kualitas manajemen aset dan risiko pembiayaan yang lebih baik daripada bank konvensional (Abd. Majid et al., 2014). Di beberapa Negara juga menunjukkan gejala yang sama, seperti di Bangladesh (Ahsan, 2016), Gambia (Barry \& Njie, 2020), Malaysia (Puspitasari et al., 2017). Tingginya nilai RGEC bank syariah belum tentu memiliki peringkat tinggi pula pada Maqashid Sharia Index (Aulia \& Indriawati, 2019).

Penilaian kinerja perbankan syariah dari aspek keuangan tentunya belum cukup, karena perbankan syariah disamping memiliki misi pemberdayaan ekonomi, juga memiliki misi dakwah dan menyebarkan rahmat bagi semesta. Maka kesesuaian dengan prinsip-prinsip syariah dan kesesuaian dengan maqashid syariah menjadi penting untuk diperhatikan (Antonio et al., 2012). Pengembangan keuangan syariah dalam keilmuan ekonomi dan keuangan Islam, baik dalam teori ataupun praktik, perlu pendekatan Maqashid Syariah. Pendekatan Maqashid Syariah berguna sebagai instrument memahami Al-Quran dan As-Sunnah. Karena katakteristik perbankan syariah saat ini, yang belum ada di masa lalu, berpotensi menimbulkan yurisprudensi yang belum diatur dalam Al-Qur'an dan As-Sunnah. Pendekatan demikian, untuk menjawab tantangan jaman dunia perbankan dan keuangan yang harus bersaing dan eksis di pasar global (Fathurrahman, 2014).

Penelitian terdahulu dengan menggunakan Maqashid Syariah Index (MSI), telah dilakukan, baik di Indonesia maupun di berbagai Negara. Penelitian yang dilakukan oleh Mifrahi \& Fakhrunnas (2018), terhadap 11 Bank Syariah di Indonesia selama 20112017 menunjukkan bahwa Maqashid-shariah-based Performance Evaluation Model (MPEM), Bank Muammalat Indonesia (BMI) memiliki nilai rata-rata tertinggi, dibandingkan bank syariah lain, namun masing-masing bank syariah memiliki kelebihan dalam elemen yang berbeda. Indeks Maqashid Syariah bank syariah di Indonesia memiliki nilai tertinggi dibanding dengan Negara-negara ASEAN (Mutia \& Musfirah, 2017), demikian juga dibandingkan dengan bank syariah di Jordania (Antonio et al., 2012).

Penilaian kinerja perbankan syariah berdasarkan indeks maqashid syariah di Indonesia telah banyak dilakukan, kebanyakan menggunakan Simple Additive Weighting (SAW) atau Maqshid Syariah Index (MSI), dan beberapa menggunakan Sharia Conformity and Profitablility (SCnP) dalam waktu dan objek yang terbatas. Penelitian ini merupakan uji maqashid syariah terhadap seluruh Bank Umum Syariah (saat ini jumlahnya 14) di Indonesia dalam jangka waktu yang panjang, yaitu 2011 sampai 2019. Sehingga penelitian ini memiliki novelty dari penelitian-penelitian sebelumnya. Tujuannya adalah, agar Uji Maqashid Syariah secara komprehensif dapat diketahui hasilnya, untuk pengembangan dunia akademik dan sebagai masukan para stake holder perbankan syariah di Indonesia maupun dunia perbankan secara umum.

\section{a. Maqashid Syariah}

Maqashid secara bahasa adalah bentuk jamak dari "maqshad" yang berarti maksud atau tujuan atau sasaran. Maqashid Syariah secara bahasa berarti maksud, tujuan atau sasaran Syariah. Abdul Malik al Juwaini adalah penggagas awal teori maqashid, kemudian dikembangkan oleh al-Ghazali $(505 \mathrm{H} / 1111$ M), dilanjutkan oleh al-Syatibi $(790 \mathrm{H} / 1388 \mathrm{M})$ dengan teori al masaalih al ammah atau kepentingan umum, berkembang kemudian dengan teori al masaalih al mursalah atau kepentingan yang tidak dibatasi dalam penjabaran tentang maqashid. 
Pembuktian maqashid syariah secara epistimologi adalah, apabila manusia dapat merasakan maslahat yang diwujudkannya (Nurnazli, 2014).

Di era modern, salah satu ulama yang melanjutkan keilmuan maqashid syariah dari para ulama klasik seperti: al Ghazali, al Shatibi, Izudin ibn Abd Salam, Ibn Taymiyah, Ibnu Qoyyim secara kontemporer, adalah Ibnu Ashur, seorang ulama kelahiran Tunisia. Di tangan ulama ini, maqashid syariah menjadi mudah diterapkan pada persoalan kekinian, sehingga syariah tetap up to date atau shalihun li kulli zaman wal makan. Ibnu Ashur dikenal sebagai perintis tiga prinsip dasar maqashid syariah yaitu: khitab al syar'iy (kondisi khitab syar'iy), al tamyiz baina al wasilah wa al maqsud (menbedakan antara prasarana dengan tujuan), dan istiqra' (induksi). Teori ini didasari dari teori maqashid al ammah dan maqashid al khassah. Atas dasar penggunaan fitrah, maslahah dan ta'lil, Ibnu Ashur menetapkan maqashid syariah secara tepat pada saat yang tepat pula. Teori maslahah yang telah dikembangkan oleh ulama sebelumnya digolongkan menjadi tiga; yaitu maslahah bagi umat, maslahah bagi kelompok atau individu dan maslahah untuk merealisasikan kebutuhan manusia (Toriquddin, 2013).

\section{b. Kinerja Perbankan Syariah Berbasis Maqashid Syariah}

Teori maqashid syariah dari al Ghazali, telah menginspirasi para cendekiawan muslim mengembangkan model maslahah untuk pembangunan dan kesejahteraan umat manusia. Nama-nama yang telah dikenal luas, seperti Abu Zahrah (1997), memperluas teori maqashid dengan memasukkan keadilan dan pendidikan, Chapra (2007), mengaplikasikan lima dasar teori maqashid syariah sebagai dasar pembangaunan dan kesejahteraan, Dusuki \& Mokhtar (2010), mengaplikasikan teori maqshid syariah sebagai dasar penerbitan Sukuk, dan masih banyak ilmuwan yang menggunakan teori maqashid syariah sebagai dasar penerapan syariah di berbagai bidang.

Abu Zaharah (1997) dalam Mohammed \& Razak (2008), telah mengklasifikasi tiga bidang besar Maqashid Syariah, yaitu: (1) Tahdhib al-Fard (Mendidik individu); (2) Iqamah al-'Adl (Menegakkan keadilan); dan (3) Jalb al-Maslahah (Mempromosikan Kesejahteraan). International Institute of Islamic Thought (IIIT) (2013), dan mengklasifikasikannya menjadi dasar tujuan perbankan syariah. Teori ini telah diadopsi dalam penelitian di berbagai sector, baik keuangan maupun non keuangan, dan telah berkembang hingga saat ini. Metode ini mengombinasikan maqashid syariah Ibnu Assur dan Abu Zaharah dengan konsep methodelogi yang dikembangkan oleh Sekaran (Mohammed et al., 2015). Konsep kinerja berbasis maqashid syariah tersebut, seperti terlihat pada tabel berikut:

Tabel 1 Tujuan, Dimensi, Elemen Kinerja Maqashid Syariah Perbankan Syariah

\begin{tabular}{|c|c|c|c|c|}
\hline $\begin{array}{l}\text { CONCEPTS } \\
\text { (OBJECTIVE) }\end{array}$ & DIMENTIONS & ELEMENTS & $\begin{array}{l}\text { PERFORMANCE } \\
\text { RATIOS }\end{array}$ & $\begin{array}{l}\text { SOURCE OF } \\
\text { DATA }\end{array}$ \\
\hline \multirow[t]{4}{*}{$\begin{array}{l}\text { 1.Educating } \\
\text { individual }\end{array}$} & \multirow[t]{2}{*}{$\begin{array}{l}\text { D1 Advancement of } \\
\text { Knowledge }\end{array}$} & $\begin{array}{l}\text { E1 Education } \\
\text { grant }\end{array}$ & $\begin{array}{l}\text { R1Education grant/total } \\
\text { income }\end{array}$ & Annual report \\
\hline & & E2 Research & $\begin{array}{l}\text { R2 Research expense/total } \\
\text { expense }\end{array}$ & Annual report \\
\hline & $\begin{array}{l}\text { D2 Instilling new skills } \\
\text { and improvement }\end{array}$ & E3 Training & $\begin{array}{l}\text { R3Training expense/total } \\
\text { expense }\end{array}$ & Annual report \\
\hline & $\begin{array}{l}\text { D3 Creating of awarness } \\
\text { of Islamic banking }\end{array}$ & E4 Publicity & $\begin{array}{l}\text { R4 Publicity expense/total } \\
\text { expense }\end{array}$ & Annual report \\
\hline \multirow{3}{*}{$\begin{array}{l}\text { 2. Establishing } \\
\text { justice }\end{array}$} & D4 Fair dealing & E5 Fair Return & R5 Profit/total income & Annual report \\
\hline & $\begin{array}{l}\text { D5 Affordable product } \\
\text { and services }\end{array}$ & $\begin{array}{l}\text { E6 Affordable } \\
\text { price }\end{array}$ & $\begin{array}{l}\text { R6 Bad debt/total } \\
\text { investment }\end{array}$ & Annual report \\
\hline & $\begin{array}{l}\text { D6 Elimination of } \\
\text { injustices }\end{array}$ & $\begin{array}{l}\text { E7 Interest free } \\
\text { product }\end{array}$ & $\begin{array}{l}\text { R7 Interest free } \\
\text { income/total income }\end{array}$ & Annual report \\
\hline \multirow{3}{*}{$\begin{array}{l}\text { 3.Public } \\
\text { interest }\end{array}$} & D7 Profitability & E8 Profit ratios & R8 Net profit/total asset & Annual report \\
\hline & $\begin{array}{l}\text { D8 Re-distribution of } \\
\text { income ang wealth }\end{array}$ & $\begin{array}{l}\text { E9 Personal } \\
\text { income }\end{array}$ & R9 Zakah/net income & Annual report \\
\hline & $\begin{array}{l}\text { D9 Investment in vital } \\
\text { real sector }\end{array}$ & $\begin{array}{l}\text { E10 Investment } \\
\text { ratios in real } \\
\text { sector }\end{array}$ & $\begin{array}{l}\text { R10 investment } \\
\text { deposit/total deposit }\end{array}$ & Annual report \\
\hline
\end{tabular}

Sumber: (Mohammed \& Razak, 2008) 


\section{Jurnal Ilmiah Ekonomi Islam, 7(01), 2021, 376}

Dari table 1 di atas dapat dijelaskan bahwa tujuan bank syariah sesuai maqashid syariah ada tiga; (1) mendidik individu (educating individual); (2) mewujudkan keadilan (establishing justice, dan (3) menjaga kepentingan umum. Dimensi dari mendidik individu (Educating individual) adalah adanya pertumbuhan pengetahuan setiap individu di dalam perbankan syariah (advancement of knowledge), elemennya adalah jumlah dana yang diinvestasikan untuk pendidikan dan riset. Pertambahan keterampilan dan pengetahuan baru (Instilling new skills and improvement), elemennya adalah besarnya biaya training yang dikeluarkan institusi. Terciptanya kesadaran tentang perbankan syariah (Creating of awarness of Islamic banking), elemennya adalah biaya publikasi tentang perbankan syariah yang disediakan. Masing-masing elemen memiliki indicator rasio seperti yang tercantum pada table 1 di atas.

Mewujudkan keadilan (establishing justice) terdapat tiga dimensi yaitu kejujuran atau kewajaran dalam memperoleh laba (fair dealing), elemennya adalah fair return dihitung dari rasio laba (profit) terhadap pendapatan total (total income). Dimensi kedua yaitu layanan yang terjangkau (affordable product and services) elemennya adalah kewajaran harga, yang diketahui dari besarnya pembiayaan bermasalah. Dimensi ketiga adalah penghapusan ketidak adilan yang didapat dari produk yang bebas bunga, dari rasio pendapatan yang terbebas dari riba dibagi dengan total pendapatan.

Tujuan menjaga kepentingan umum memiliki dimensi profitability (kemampuan menghasilkan laba), dengan elemen ROA, dimensi redistribusi kekayaan elemennya adalah besarnya zakat yang telah disalurkan terhadap pendapatan bersih (net income), dimensi investasi pada sector yang penting (investment in vital sector riil) elemennya adalah jumlah investasi pada sector riil yang vital dengn rumus investment deposit dibagi dengan total deposit.

Dimensi dan elemen yang telah ditetapkan seperti terlihat pada table $1 \mathrm{di}$ atas, diberi nilai atau bobot masing-masing dimensi yang terimplementasi pada elemen yang dimiliki. Adapun besaran bobot dapat dilihat pada table 2 di atas.

\section{c. Penelitian Terdahulu}

Kinerja perbankan syariah berlandaskan maqashid syariah, yang telah dikembangkan oleh para cendekiawan muslim kontemporer sebagai alat ukur kepatuhan syariah berdasarkan tujuannya, telah dipergunakan oleh para peneliti dunia akademik sebagai alat ukur kinerja perbankan dan keuangan syariah. Namun secara regulative, instrument ini belum ditetapkan sebagai alat ukur kinerja dalam praktis. Penelitan terdahulu telah membuktikan efektifitas Indeks Maqashid Syariah (IMS) sebagai pengukur kinerja perbankan syariah. Kinerja keuangan perbankan syariah secara umum menunjukkan hasil yang menggembirakan, seperti: tingkat kesehatan Bank BNI Syari'ah dengan menggunakan metode CAMELS menunjukkan Sangat Sehat, sedangkan dengan menggunakan metode RGEC rata- rata menunjukkan predikat Sehat (Hafiz, 2018). Rasio CAMEL berpengaruh pada kesehatan di BTN Syariah (Novyanti \& Roestiono, 2014), bank syariah di Indonesia memiliki tingkat kualitas manajemen aset dan risiko pembiayaan yang lebih baik daripada bank konvensional (Abd. Majid et al., 2014). Di beberapa Negara juga menunjukkan gejala yang sama, seperti di Bangladesh (Ahsan, 2016), Gambia (Barry \& Njie, 2020), Malaysia (Puspitasari et al., 2017).

Tujuan utama perbankan syariah adalah sebagai lembaga yang mengupayaan tercapainya social welfare kepada umat manusia secara luas. Penelitian Febriadi (2017), menyarankan agar maqashid syariah menjadi sandaran dalam operasional $\mathrm{dn}$ pengembangan produk perbankan syariah dengan merevitalisasi konsep maqashid syariah Abu Zahrah dan Abdul Majid Najjar (Wasyith, 2017). Maka sudah semestinya lembaga otoritas seperti Otoritas Jasa Keuangan (OJK), Dewan Syariah Nasional-Majelis Ulama Indonesia (DSN-MUI), Bank Indonesia (BI), Lembaga Penjamin Simpanan (LPS) mempertimbangkan factor maslahat di tingkat mikro dan makro pada perbankan syriah di Indonesia (Qoyum, 2018). Demikian pula di tingkat internasional seperti AAOIFI dan IBFI (Ayub, 2018). Maka dari itu para praktisi perbankan dan keuangan dapat meningkatkan literasi keuangan syariah secara intensif (Abdul et al., 2020), karena sampai saat ini masih terdapat shubuhat dalam produk dan operasional perbankan syariah (Ahmed et al., 2017).

Penelitian yang dilakukan oleh Prasetyowati \& Handoko (2019) dengan model Shariah Confirmaty and Profitability (SCnP) tahun 2010-2014, mengindikasikan bahwa perbankan syariah di Indonesia masih berada di kuadran kiri bawan dan kanan bawah. Artinya kinerja maqshid syariahnya masih rendah. Dengan metode yang sama penelitian Ramdhoni \& Fauzi, (2020) tahun 2012-2016, 
menunjukkan hasil rendahnya kinerja maqashid syariah di Indonesia, namun kinerja keuangannya menunjukkan indikasi yang sehat Aam Slamet Rusydiana et al. (2018). Maka dari itu bank syariah harus memperhatikan kinerja berbasis maqashid syariah untuk meningkatkan bankability (Hasan \& Dewi, 2019). Dengan menggabungkan dua tujuan, syariah dan ekonomi, Sharia Conformity and Profitability (SCnP) lebih efektif dalam mengukur kinerja bank syariah (Muchtar \& Rofi, 2020).

Perbankan syariah idealnya fokus dalam pembiayaan bagi hasil, karena sampai saat ini akadakad yang memberikan hasil di muka seperti murabahah, istishna, ijarah dan variasinya masih mendominasi produk perbankan syariah di semua Negara. Komitmen mewujudkan maqashid syariah harus didominasi oleh akan mudahrabah dan musyarakah. Penelitian yang dilakukan oleh Amaroh \& Masturin (2018), telah membuktikan bahwa pembiayaan bagi hasil berpengaruh positif terhadap kinerja maqashid syariah, perilaku mengambil risiko dan efisiensi biaya tidak berpengaruh terhadap kinerja maqashid syariah. Demikian pula zakat, modal intelektual, peran dewan pengawas syariah, berpengaruh positif terhadap kinerja maqashid syariah (Andraeny \& Putri, 2017). Tingginya nilai RGEC bank syariah belum tentu memiliki peringkat tinggi pula pada Maqashid Sharia Index (Aulia \& Indriawati, 2019).

Secara empirik, indeks maqashid shariah perbankan syariah di Indonesia juga berpengaruh positif terhadap kinerja keuangan (Hidayat et al., 2019). Maka sudah semestinya lembaga otoritas seperti Otoritas Jasa Keuangan (OJK), Dewan Syariah Nasional-Majelis Ulama Indonesia (DSN-MUI), Bank Indonesia (BI), Lembaga Penjamin Simpanan (LPS) mempertimbangkan factor maslahat di tingkat mikro dan makro pada perbankan syriah di Indonesia (Qoyum, 2018). Demikian pula di tingkat internasional seperti AAOIFI dan IBFI (Ayub, 2018). Persaingan global menghendaki perbankan syariah menjaga tingkat risiko dengan kepatuhan syariah secara seimbang (Hajera Fatima Khan, 2017), agar tidak terimbas era disrupsi (A. Rusydiana et al., 2019).

\section{METODE PENELITIAN}

Penelitian ini adalah penelitian kuantitatif deskriptif, menggunakan Simple Additive Weighting (SAW). SAW digunakan sebagai metode pemeringkatan kinerja perbankan syariah berdasarkan hasil akhir dari Maqashid Shariah Index (MSI). Data yang digunakan adalah data sekunder yang berasal dari Annual Report Bank Umum Syariah (BUS) dari 2011- 2019. Populasi data adalah 14 Bank Umum Syariah (BUS) di Indonesia, 14 BUS tersebut menjadi sampel jenuh, sesuai ketersediaan data yang dibutuhkan selama periode penelitian ini (jangka waktu 2011-2019). 14 Bank Umum Syariah tersebut adalah: (1) Bank Muamalat Indonesia (BMI), (2) Bank BRI Syariah (BRIS), (3) Bank Syariah Mandiri (BSM), (4) Bank BNI Syariah (BNIS), (5) Mega Syariah (BMS), (6) Bank Panin Syariah (BPS), (7) Bank Syariah Bukopin (BSB), (8) Bank BCA Syariah (BCAS), (9) Bank Victoria Syariah (BVS), (10) Bank Jabar dan Banten Syariah (BJBS), (11) Maybank Syariah (Maybank), (12) BTPN Syariah (BTPNS), (13) BPD Nusa Tenggara Barat Syariah (BNTBS), (14) Bank Aceh Syariah (BAS).

Perhitungan Maqashid Shariah Index (MSI) mengombinasikan maqashid syariah Ibnu Assur dan Abu Zaharah dengan konsep methodelogi yang dikembangkan oleh Sekaran (Mohammed et al., 2015). Abu Zaharah (1997) dalam Mohammed \& Razak (2008), telah mengklasifikasi tiga bidang besar Maqashid Syariah, yaitu: (1) Tahdhib al-Fard (Mendidik individu); (2) Iqamah al-'Adl (Menegakkan keadilan); dan (3) Jalb al-Maslahah (Mempromosikan Kesejahteraan). International Institute of Islamic Thought (IIIT) (2013), dan mengklasifikasi menjadi dasar tujuan perbankan syariah. Klasifikasi tujuan tersebut diberi bobot sebagaimana table berikut:

Tabel 2 Bobot MSI Perbankan Syariah berdasar Tujuan, Dimensi dan Elemen

\begin{tabular}{|c|c|c|c|}
\hline $\begin{array}{c}\text { CONCEPTS } \\
\text { (OBJECTIVE) }\end{array}$ & $\begin{array}{l}\text { DIMEN } \\
\text { TIONS }\end{array}$ & ELEMENTS & $\begin{array}{c}\text { AVERAGE } \\
\text { WEIGHT } \\
\end{array}$ \\
\hline \multirow[t]{5}{*}{$\begin{array}{l}\text { 1. Educating } \\
\text { individual }\end{array}$} & \multirow{4}{*}{30} & $\begin{array}{l}\text { E1 Education } \\
\text { grant }\end{array}$ & 24 \\
\hline & & E2 Research & 27 \\
\hline & & E3 Training & 26 \\
\hline & & E4 Publicity & 23 \\
\hline & & Total & 100 \\
\hline \multirow{3}{*}{$\begin{array}{l}\text { 2. Establishin } \\
\text { g justice }\end{array}$} & \multirow{3}{*}{41} & E5 Fair Return & 30 \\
\hline & & $\begin{array}{l}\text { E6 Affordable } \\
\text { price }\end{array}$ & 32 \\
\hline & & $\begin{array}{l}\text { E7 Interest free } \\
\text { product }\end{array}$ & 38 \\
\hline & & Total & 100 \\
\hline & & & \\
\hline
\end{tabular}


Jurnal Ilmiah Ekonomi Islam, 7(01), 2021, 378

\begin{tabular}{|l|c|l|c|}
\hline $\begin{array}{c}\text { CONCEPTS } \\
\text { (OBJECTIVE) }\end{array}$ & $\begin{array}{l}\text { DIMEN } \\
\text { TIONS }\end{array}$ & ELEMENTS & $\begin{array}{c}\text { AVERAGE } \\
\text { WEIGHT }\end{array}$ \\
\hline $\begin{array}{l}\text { 3. Public } \\
\text { interest }\end{array}$ & 29 & E8 Profit ratios & 33 \\
\cline { 3 - 4 } & $\begin{array}{l}\text { E9 Personal } \\
\text { income }\end{array}$ & 30 \\
\cline { 3 - 4 } & $\begin{array}{l}\text { E10 Investment } \\
\text { ratios in real } \\
\text { sector }\end{array}$ & 37 \\
\hline Total & 100 & Total & 100 \\
\hline
\end{tabular}

Sumber: (Mohammed \& Razak, 2008)

Bobot di atas kemudian dimasukkan sesuai data hasil penelitian dengan formula matematis berikut:

Indeks Tujuan1: Educating Individual, dihitung dengan formula berikut:

$I K-T 1=I K 11+I K 21+I K 31+I K 41$

Dimana;

$\mathrm{T} 1=$ Tujuan Pertama dari Maqashid Syariah (Pendidikan/Educating Individual)

IK11 = Indikator Kinerja dari Jumlah Elemen Pertama Tujuan 1 (Hibah Pendidikan)

IK21 = Indikator Kinerja dari Jumlah Elemen Kedua Tujuan 1 (Penelitian)

IK31 = Indikator Kinerja dari Jumlah Elemen Ketiga Tujuan 1 (Pelatihan)

IK41 = Indikator Kinerja dari Jumlah Elemen Keempat Tujuan 1 (Publikasi)

Indeks Tujuan 2: Establishing justice (Keadilan) dihitung dengan formula berikut:

$I K-T 2=I K 12+I K 22+I K 32$

Dimana;

$\mathrm{T} 2=$ Tujuan Kedua dari Maqashid Syariah (Keadilan)

IK12 = Indikator Kinerja dari Jumlah Elemen $\begin{array}{lll}\text { Pertama Tujuan } & 2 & \text { (Fair }\end{array}$

Return/Pengembalian yang adil)

IK22 = Indikator Kinerja dari Jumlah Elemen Kedua Tujuan 2 (Fair Price/ Harga yang adil)

IK32 = Indikator Kinerja dari Jumlah Elemen Ketiga Tujuan 2 (Produk Bebas Bunga)

Indeks Tujuan 3: Public Interest (Kesejahteraan) dihitung dengan formula berikut:

$I K-T 3=I K 13+I K 23+I K 33$

Dimana;

T3 = Tujuan Ketiga dari Maqashid Syariah (Kesejahteraan)

IK13 = Indikator Kinerja dari Jumlah Elemen Pertama Tujuan 3 (Rasio Laba)
IK21 = Indikator Kinerja dari Jumlah Elemen Kedua Tujuan 2 (Transfer Pendapatan)

IK33 = Indikator Kinerja dari Jumlah Elemen Ketiga Tujuan 2 (Rasio Investasi Sektor Rill)

MSI adalah hasil rata-rata dari tiga tujuan diatas, atau:

IK-T1 = Rata-Rata dari Indikator Kinerja Tujuan Pertama

IK-T2 = Rata-Rata dari Indikator Kinerja Tujuan Kedua

IK-T3 = Rata-Rata dari Indikator Kinerja Tujuan Ketiga

\section{HASIL DAN PEMBAHASAN}

Kepatuhan syariah pada perbankan syariah menjadi tanggung jawab Dewan Pengawas Syariah (DPS) masing-masing bank syariah. Setiap bank syariah wajib memiliki DPS yang bertugas mengontrol kesesuaian syariah setiap bank syariah (Ahmed et al., 2017). Kepatuhan syariah bank syariah diukur dari kesesuaian produk dan operasional bank syriah dengan fatwa yang telah dikeluarkan oleh DSN-MUI. Bila produk dan operasional bank syariah tidak menyimpang dari fatwa DSN-MUI, maka dapat dikatakan bahwa produk dan operasional bank syariah tersebut telah seusai dengan prinsip-prinsip syariah. Bila belum sesuai dengan fatwa DSN-MUI, maka DPS dapat membuat keputusan bahwa bank syariah tersebut belum memenuhi prinsip-prinsip syariah (Muqorobin \& Cahyo, 2019).

Selain DSN-MUI, dalam praktis perbankan secara internaasional, terdapat organisasi-organisasi yang dapat menjadi standar kepatuhan syariah, seperti: Islamic Financial Services Board (IFSB), Accounting and Auditing Organization for Islamic Financial Institution (AAOIFI), dan International Islamic Financial Market (IIMF). Dari organisasiorganisasi di atas, otoritas keuangan Negara-negara Islam maupun non muslim mengambil patokan standard kepatuhan pada prinsip-prinsip syariah.

Sesuai konsep Ibn Ashur, oleh Abu Zaharah, kinerja maqashid syariah pada perbankan syariah adalah: pertama; pendidikan individu/educating individual (tandzibul al-fard), kedua perwujudan keadilan/establishing justice (iqamah al-'adl), dan ketiga kesejahteraan/public interrest (jalb almaslahah) oleh Mohammed \& Razak, (2008), menggunakan metodologi Sekaran dalam 


\section{Jurnal Ilmiah Ekonomi Islam, 7(01), 2021, 379}

(Mohammed et al., 2015), hasil perhitungannya seperti terlihat pada tabel berikut:

Tabel 3 Indikator Kinerja Tujuan 1: Educating Individual Bank Syariah di Indonesia 2011-2019

\begin{tabular}{|c|c|c|c|c|c|c||}
\hline \multirow{2}{*}{ BANK } & \multicolumn{2}{|c|}{ Indikator Kinerja Tujuan 1 : Educating Individual } & \multirow{2}{*}{ Jumlah } & \multirow{2}{*}{$\begin{array}{c}\text { RATA- } \\
\text { RATA }\end{array}$} \\
\cline { 2 - 5 } & E1 & E2 & E3 & E4 & & 0.0026 \\
\hline BMI & 0.0050 & 0.0016 & 0.0058 & 0.0113 & 0.0237 & 0.0019 \\
\hline BSM & 0.0044 & 0.0003 & 0.0056 & 0.0071 & 0.0174 & 0.0015 \\
\hline BPS & 0.0024 & 0 & 0.0034 & 0.0073 & 0.0131 & 0.0016 \\
\hline BRIS & 0.0020 & 0 & 0.0034 & 0.0088 & 0.0142 & 0.0049 \\
\hline BNIS & 0.0094 & 0 & 0.0123 & 0.0224 & 0.0441 & 0.0008 \\
\hline BVS & 0.0027 & 0 & 0.0003 & 0.0041 & 0.0071 & 0.0011 \\
\hline BCAS & 0.0057 & 0 & 0.0011 & 0.0027 & 0.0095 & 0.0008 \\
\hline BMS & 0.0021 & 0 & 0.0032 & 0.0020 & 0.0073 & 0.0018 \\
\hline BSB & 0 & 0 & 0.0014 & 0.0087 & 0.0163 & 0.0002 \\
\hline BJBS & 0 & 0.0003 & 0 & 0.0015 & 0.0018 & 0.0014 \\
\hline Maybank & 0.0048 & 0 & 0.0064 & 0.0014 & 0.0126 & 0.0031 \\
\hline BTPNS & 0.0088 & 0 & 0.0095 & 0.0095 & 0.0278 & 0.0005 \\
\hline BNTBS & 0 & 0 & 0.0016 & 0.0031 & 0.0047 & 0.0014 \\
\hline BAS & 0.0052 & 0 & 0.0056 & 0.0019 & 0.0127 & 0 \\
\hline
\end{tabular}

Kinerja Tandzibul al-Fard atau Educating Individual mencakup elemen tujuan pertama yang dihitung dari Hibah Pendidikan (E1), Penelitian (E2), Pelatihan (E3) dan Publikasi (E4). Dari tabel di atas, secara rata-rata BNIS memiliki nilai tertinggi yaitu 0.0049 , disusul BTPNS dengan nilai 0,0031, BMI 0.0026 , dan BSM 0.0019. Sedangkan nilai terendah adalah BJBS 0.0002, BNTBS 0.0005, BMS dan BVS yang memiliki nilai sama 0.0008 .

Rendahnya indeks Educating Individual perbankan syariah di Indonesia menunjukkah ketidak pedulian pada aspek pengembangan Sumber Daya Insani (SDI). Padahal Intelektual Capital (IC), dan Islamic Corporate Governance (ICG) sesuai penelitian yang dilakukan oleh (Hartono, 2018), Indeks di atas berdampak pada peningkatan nilai MSI bank syariah. MSI juga berpengaruh positif terhadap alokasi CSR bank syariah di ASEAN (Hasan \& Dewi, 2019).

Rata-rata nilai indeks Tujuan 1 perbankan syariah di Indonesia adalah 0,17 . Artinya hanya 5 bank yang berada di atas rata-rata, sedangkan 9 bank lainnya dibawah nilai rata-rata. Peringkat indeks, rata-rata dan posisi bank berada di atas atau di bawah rata-rata dapat dilihat dari grafik dibawah ini:

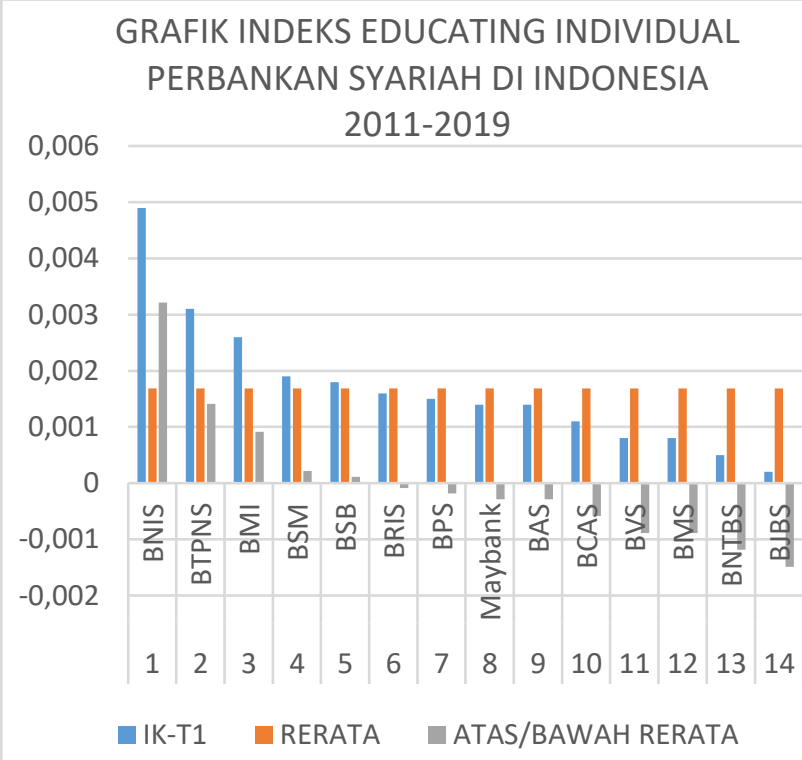

Grafik 1 Indeks Tujuan 1: Educating Individual

Perbankan Syariah di Indonesia 2011-2019

Dari grafik di atas terlihat peringkat pertama yaitu BNIS, disusul kemudian kedua BTPNS, ketiga BMI, keempat BSM, kelima BSB, keenam BRIS, ketujuh BPS, kedelapan Maybank, kesembilan BAS, kesepuluh BCAS, kesebelas BVS, keduabelas BMS, ketigabelas BNTBS keempatbelas atau terakhir adalah BJBS. Bank yang indeksnya di atas rata-rata adalah BNIS, BTPNS, BMI, BSM dan BSB, selebihnya atau 9 bank syariah indeks Educating Individualnya berada dibawah rata-rata. 


\section{Jurnal Ilmiah Ekonomi Islam, 7(01), 2021, 380}

Tabel 4 Indikator Kinerja Tujuan 2: Keadilan

(Establishing Justice) Bank Syariah di Indonesia 2011-2019

\begin{tabular}{|c|c|c|c|c|c|}
\hline \multirow{4}{*}{ BANK } & \multicolumn{3}{|c|}{$\begin{array}{c}\text { Indikator Kinerja } \\
\text { Tujuan 2: } \\
\text { Establishing } \\
\text { Justice/Keadilan }\end{array}$} & Jumlah & $\begin{array}{c}\text { RATA- } \\
\text { RATA }\end{array}$ \\
\cline { 2 - 6 } & E5 & E6 & E7 & & \\
\hline BMI & 0.0084 & 0.3955 & 0.8706 & 1.2746 & 0.1416 \\
\hline BSM & 0.0045 & 0.2474 & 0.9441 & 1.1960 & 0.1329 \\
\hline BPS & 0.0073 & 0.6646 & 0.8654 & 1.5373 & 0.1708 \\
\hline BRIS & 0.0062 & 0.2926 & 0.9044 & 1.2032 & 0.1337 \\
\hline BNIS & 0.0064 & 0.1877 & 0.8665 & 1.0606 & 0.1178 \\
\hline BVS & 0.0103 & 0.5377 & 0.9199 & 1.4679 & 0.1631 \\
\hline BCAS & 0.0107 & 0.4330 & 0.9143 & 1.3580 & 0.1509 \\
\hline BMS & 0.0048 & 0.1330 & 0.7325 & 0.8703 & 0.0967 \\
\hline BSB & 0.0046 & 0.4455 & 0.8794 & 1.3295 & 0.1477 \\
\hline BJBS & 0.0004 & 0.1991 & 0.7918 & 0.9913 & 0.1101 \\
\hline Maybank & 0.0033 & 0.0718 & 0.7534 & 0.8285 & 0.0921 \\
\hline BTPNS & 0.0033 & 0.0004 & 0.7766 & 0.7803 & 0.0867 \\
\hline BNTBS & 0.0026 & 0.0814 & 0.2287 & 0.3127 & 0.0347 \\
\hline BAS & 0.0034 & 0.0492 & 0.5285 & 0.5811 & 0.0646 \\
\hline
\end{tabular}

Tujuan 2 dalam table di atas adalah indikator perwujudan Keadilan (Establishing Justice), yang terdiri dari elemen Fair Return (E5), Affordable Price (E6) dan Interest Free product (E7). Dari table di atas kinerja Establishing Justice dengan rata-rata nilai tertinggi adalah BPS dengan nilai rata-rata 0,1708, disusul oleh BVS 0,1631, BSB 0,1477 dan BMI 0,1416. Nilai terendah adalah BNTBS dengan 0.0347, BAS 0.0646, dan BTPNS 0.0867. Peringkat, rerata dan yang berada di posisi bawah atau atas rerata dari indeks tujuan 2 ini, dapat dilihat dari grafik di bawah ini:

GRAFIK INDEKS ESTABLISHING JUSTICE PERBANKAN SYARIAH DI INDONESIA 2011-2019

0,2000

0,1500

0,1000

0,0500

0,0000

$-0,0500$

$-0,1000$

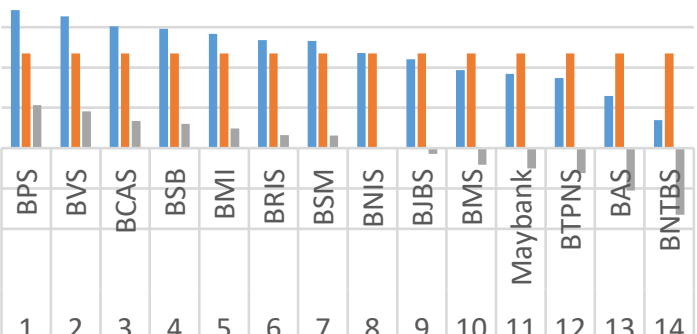

-IK-T2 $\square$ RERATA $\square$ ATAS/BAWAH RERATA

Grafik 2 Indeks Tujuan 2: Establishing Justice

Perbankan Syriah di Indonesia tahun 2011-2019
Dari grafik di atas terlihat bahwa peringkat indeks tujuan 2 (establishing justice) perbankan syariah di Indonesia adalah posisi pertama BPS, kedua BVS, ketiga, BCAS, keempat BSB, kelima BMI, keenam BRIS, ketujuh BSM, kedelapan BNIS, kesembilan BJBS, kesepuluh BMS, kesebelas Maybank, keduabelas BTPNS, ketigabelas BAS, terakhir adalah BNTBS. Rata-rata indeks tujuan 2 perbankan syariah di Indonesia 2011-2019 adalah 0,12 . Ada delapan bank yang berada di atas rerata, sedangkan 5 bank dari peringkat Sembilan sampai terakhir berada dibawah rata-rata indeks establishing justice.

Tabel 5 Indikator Kinerja Tujuan 3: Kesejahteraan (Public Interest) Bank Syariah di Indonesia 20112019

\begin{tabular}{|c|c|c|c|c|c|}
\hline \multirow{2}{*}{ BANK } & \multicolumn{3}{|c|}{$\begin{array}{l}\text { Indikator Kinerja Tujuan } \\
\text { 3: Kesejahteraan/Public }\end{array}$} & Jumlah & $\begin{array}{c}\text { RATA- } \\
\text { RATA }\end{array}$ \\
\cline { 2 - 6 } & E8 & E9 & E10 & & \\
\hline BMI & 0.0009 & 0 & 0.4852 & 0.4861 & 0.0540 \\
\hline BSM & 0.0040 & 0.0001 & 0.4879 & 0.4920 & 0.0547 \\
\hline BPS & $(0.0085)$ & 0 & 0.5609 & 0.5524 & 0.0614 \\
\hline BRIS & 0.0021 & 0.0001 & 0.4940 & 0.4962 & 0.0551 \\
\hline BNIS & 0.0054 & 0.0001 & 0.5219 & 0.5274 & 0.0586 \\
\hline BVS & $(0.0015)$ & 0 & 0.4778 & 0.4763 & 0.0529 \\
\hline BCAS & 0.0040 & 0 & 0.5448 & 0.5488 & 0.0610 \\
\hline BMS & 0.0054 & 0.0001 & 0.5502 & 0.5557 & 0.0617 \\
\hline BSB & 0.0013 & 0 & 0.6009 & 0.6022 & 0.0669 \\
\hline BJBS & $(0.0095)$ & 0 & 0.5992 & 0.5897 & 0.0655 \\
\hline Maybank & $(0.0256)$ & 0 & 0.3448 & 0.3192 & 0.0355 \\
\hline BTPNS & 0.0319 & 0 & 0.2730 & 0.3049 & 0.0339 \\
\hline BNTBS & 0.0023 & 0 & 0.1837 & 0.1860 & 0.0207 \\
\hline BAS & 0.0059 & 0 & 0.2371 & 0.2430 & 0.0270 \\
\hline
\end{tabular}

Hasil perhitungan indikator Kesejahteraan (Public Interest), yang terdiri dari elemen Fair Profit ratios (E8), Personal income (E9) dan Investment ratios in real sector (E10. kinerja bank syariah di Indonesia menunjukkan bahwa BSB memiliki nilai tertinggi, yaitu 0,0669, kemudian BJBS 0,0655, BMS 0,0617 dan BPS 0,0614 kemudian BCAS 0,0610. Sedangkan kinerja terendah pada tujuan ini adalah BNTBS 0.0207 kemudian BAS 0,0270 dan BTPNS 0,0339 .

Peringkat indeks tujuan 3 (public interest), rerata dan posisi bank yang berada di atas maupun dibawah rerata, dapat dilihat dari grafik di bawah ini: 
GRAFIK INDEX PUBLIC INTEREST PERBANKAN SYARIAH DI INDONESIA 2011-2019

\section{0,0800}

0,0600

0,0400

0,0200

0,0000

$-0,0200$

$-0,0400$
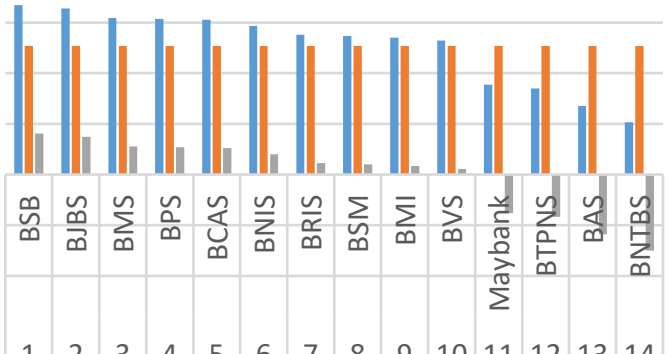

$\begin{array}{lllllllllllllllll}1 & 2 & 3 & 4 & 5 & 6 & 7 & 8 & 9 & 10 & 11 & 12 & 13 & 14\end{array}$

-IK-T3 RERATA $\square$ ATAS/BAWAH RERATA

Grafik 3 Indeks Tujuan 3: (Public Interest)

Perbankan Syariah di Indonesia 2011-2019

Dari grafik di atas terlihat bahwa peringkat indeks tujuan 3 ini teratas asalah BSB, kedua BJBS, ketiga BMS, keempat BPS, kelima BCAS, keenam BNIS, ketujuh BRIS, kedelapan BSM, kesembilan BMI, kesepuluh, BVS, kesebelas Maybank, keduabelas BTPNS, ketigabelas BAS, terakhir atau keempatbelas adalah BNTBS. Sepuluh bank indeksnya berada di atas rerata, sedangkan empat bank lainnya yaitu Maybank, BTPNS, BAS dan BNTBS indeksnya berada di bawah rerata atau dibawah 0,051. Tabel 6 MSI Bank Syariah di Indonesia tahun 20112019

\begin{tabular}{|c|c|c|c|c|}
\hline \multirow{2}{*}{ BANK } & \multicolumn{4}{|c|}{ Maqashid Shariah Index (MSI) } \\
\cline { 2 - 5 } & IK-T1 & IK-T2 & IK-T3 & Jumlah \\
\hline BMI & 0.0026 & 0.1416 & 0.0540 & 0.1983 \\
\hline BSM & 0.0019 & 0.1329 & 0.0547 & 0.1895 \\
\hline BPS & 0.0015 & 0.1708 & 0.0614 & 0.2336 \\
\hline BRIS & 0.0016 & 0.1337 & 0.0551 & 0.1904 \\
\hline BNIS & 0.0049 & 0.1178 & 0.0586 & 0.1814 \\
\hline BVS & 0.0008 & 0.1631 & 0.0529 & 0.2168 \\
\hline BCAS & 0.0011 & 0.1509 & 0.0610 & 0.2129 \\
\hline BMS & 0.0008 & 0.0967 & 0.0617 & 0.1593 \\
\hline BSB & 0.0018 & 0.1477 & 0.0669 & 0.2164 \\
\hline BJBS & 0.0002 & 0.1101 & 0.0655 & 0.1759 \\
\hline Maybank & 0.0014 & 0.0921 & 0.0355 & 0.1289 \\
\hline BTPNS & 0.0031 & 0.0867 & 0.0339 & 0.1237 \\
\hline BNTBS & 0.0005 & 0.0347 & 0.0207 & 0.0559 \\
\hline BAS & 0.0014 & 0.0646 & 0.0270 & 0.0930 \\
\hline
\end{tabular}

Untuk mendapatkan MSI, langkahnya adalah menjumlahkan ketiga tujuan yang telah diperoleh seperti terlihat pada table sebelumnya. Dari hasil perhitungan tiga tujuan pada tabel, kemudian dibuat nilai rata-rata untuk mengukur Indeks Maqashid Syariah (IMS) secara keseluruhan. Peringkat indeks, rerata dan yang berada di posisi di atas atau dibawah rerata, dapat dilihat seperti pada grafik dibawah ini:

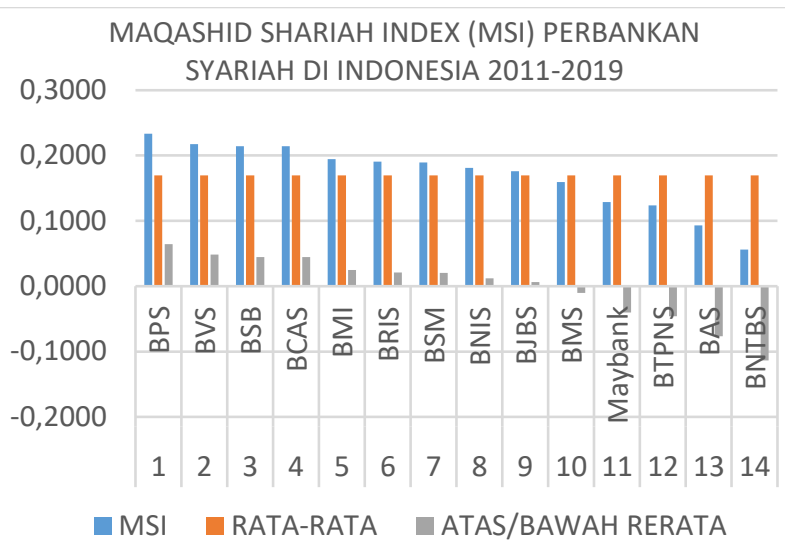

Grafik 4 Maqashid Shariah Index (MSI) Perbankan Syariah di Indonesia tahun 2011-2019

Nilai IMS tertinggi peringkat pertama adalah BPS dengan skor 0,2336, peringkat kedua BVS dengan nilai 0,2168, peringkat ketiga adalah BSB dengan nilai 0,2164 , peringkat keempat adalah BCAS dengan skor 0,2129, peringkat kelima adalah BMI dengan nilai 0,1983, peringkat keenam adalah BSM dengan nilai 0,1895 , peringkat ketujuh BRIS dengan skor 0,1904, kedelapan BNIS dengan nilai 0,1814, kesembilan BJBS 0,1759, kesepuluh BMS 0,1593, kesebelas adalah Maybank dengan nilai 0,1289, keduabelas BTPNS 0,1237, ketigabelas BAS 0,0930, dan terakhir keempatbelas adalah BNTBS dengan nilai 0,1289 . Rata-rata IMS bank syariah di Indonesia tahun 2011-2019 adalah 0,1694, ada 5 bank yang nilai indeks maqashid syariahnya dibawa rerata, yaitu BMS, Maybank, BTPNS, BAS, dan BNTBS. Hasil ini sejalan dengan penelitian Wahid et al., (2018), dari perhitungan MSI tahun 2012-2016 yang menempatkan BPS di peringkat terbaik, sedangkan Wahyuni et al. (2020), dari perhitungan IMS tahun 2012-2018 menempatkan BPS diperingkat dua, peringkat pertama ditempati BSM, peringkat ketiga BCAS.

Hasil di atas tidak berbeda jauh dengan penelitian yang dilakukan oleh Al-Ghifari et al., (2020), dari empat bank syariah di Indonesia (BSM,BMI, BRIS, BNIS) dan empat bank syariah di Malaysia (Bank Islam Malaysia Berhad, CIMB Islamic Bank, Maybank Islamic Berhad dan RHB Islamic Bank) tahun 2011-2014, BMI menduduki IMS tertinggi 0,1512, sedangkan bank syariah Malaysia adalah CIMB Islamic Bank dengan indeks 0,0702. Sejalan dengan hasil penelitian (Antonio et al., 2012), membandingkan dua bank syariah di Indonesia (BSM dan BMI) dengan dua bank syariah di Jordania (Jordan Islamic Bank (JIB) dan Islamic International Arab 
Jordan Bank (IIABJ), hasil indeks mengindikasikan bahwa BMI memiliki IMS tertinggi 0,17839, BSM 0,16190 lebih tinggi dari dua bank di Jordan, IIABJ 0,10295 dan JIB 0,08152. Indeks Maqashid Shariah secara simultan mempengaruhi 34,9\% ROA dan 39,7\% ROE (Hidayat et al., 2019). Maka saran atas penelitian yang dilakukan oleh (Rao, 2018) adalah bank syariah harus mengedepankan peringkat "S" (Syariah): dalam CAMELS, dan saran dari (Hasan \& Dewi, 2019), bahwa bank syariah harus memperhatikan kinerja berbasis maqashid syariah untuk meningkatkan bankability.

Maka dari itu, indikator maqashid syariah perlu diterapkan di perbankan syariah, regulator dan otoritas perlu mengembangkan alat ukur berbasis syariah (Mukhibad et al., 2020), dan secara kolektif menghasilkan keputusan pengukuran kinerja berbasis maqashid syariah (Rashidah \& Faisal, 2015). Sejalan dengan hasil penelitian (Nazreen Tabassum \& Fahim, 2015), yang menyarankan otoritas perbankan dan keuangan Malaysia serta Peradilan mengupayakan penerapan hukum Syariah, untuk meyakinkan kepercayaan publik dan investor terhadap perbankan Islam di Malaysia.

\section{KESIMPULAN \\ Simpulan}

Rata-rata IMS bank syariah di Indonesia tahun 2011-2019 adalah 0,1694, ada 5 bank yang nilai indeks maqashid syariahnya dibawa rerata, yaitu BMS, Maybank, BTPNS, BAS, dan BNTBS. Nilai IMS tertinggi peringkat pertama adalah BPS dengan skor 0,2336 , peringkat kedua BVS dengan nilai 0,2168 , peringkat ketiga adalah BSB dengan nilai 0,2164 , peringkat keempat adalah BCAS dengan skor 0,2129 , peringkat kelima adalah BMI dengan nilai 0,1983 , peringkat keenam adalah BSM dengan nilai 0,1895, peringkat ketujuh BRIS dengan skor 0,1904, kedelapan BNIS dengan nilai 0,1814, kesembilan BJBS 0,1759, kesepuluh BMS 0,1593, kesebelas adalah Maybank dengan nilai 0,1289 , keduabelas BTPNS 0,1237, ketigabelas BAS 0,0930, dan terakhir keempatbelas adalah BNTBS dengan nilai 0,1289.

\section{Saran}

Pengukuran kinerja perbankan syariah berbasis Maqashid Syariah sudah waktunya dilakukan di dunia praktis. Regulator seperti Bank Indonesia (BI), Otoritas Jasa Keuangan (OJK), Dewan Syariah Nasional-Majelis Ulama Indonesia (DSN-MUI) seharusnya membuat standar kinerja berbasis syariah untuk mengukur kinerja perbankan syariah, disamping ukuran kinerja ekonomi yang saat ini diberlakukan.

\section{UCAPAN TERIMAKASIH}

Penghargaan dan ucapan terima kasih kepada Direktorat Riset dan Pengabdian Masyarakat, Deputi Bidang Penguatan Riset dan Pengembangan, Kementerian Riset dan Teknologi / Badan Riset dan Inovasi Nasional, melalui LL Dikti Wilayan VI dan Lembaga Penelitian dan Pengabdian Masyarakat (LPPM) Universitas Islam Nahdlatul Ulama (UNISNU) Jepara. Penelitian ini adalah penelitian Kompetif Nasional, skema Penelitian Dosen Pemula (PDP) tahun anggaran 2019-2020

\section{DAFTAR PUSTAKA}

Abd. Majid, M. S., Musnadi, S., \& Putra, I. Y. (2014). A comparative analysis of the quality of Islamic and conventional banks' asset management in Indonesia. Gadjah Mada International Journal of Business, 16(2), 185-200. https://doi.org/10.22146/gamaijb.5463

Abdul, M., Chowdhury, M., Masud, A. Al, \& Tanvir, J. I. (2020). Contemporary Responses to the Criticism of Islamic Banks in Malaysia. August. https://doi.org/10.13135/2421-2172/4307

Abu Zahrah, M. (1997). Ușūl al-fiqh. Cairo: Dār alFikr al- 'Arabī.

Ahmed, E. R., Yahya, S., \& Haron, H. (2017). Shubuhat Activities in Islamic Banking. Jurnal Akuntansi Dan Bisnis, 10(January), 1-15. http://jab.fe.uns.ac.id/index.php/jab/article/view/ 110

Ahsan, M. K. (2016). Measuring Financial Performance Based on CAMEL: A Study on Selected Islamic Banks in Bangladesh. Asian Business Review, 6(1), https://doi.org/10.18034/abr.v6i1.803

Al-Ghifari, M., Handoko, L. H., \& Yani, E. A. (2020). Analisis Kinerja Perbankan Syariah Di Indonesia Dan Malaysia Dengan Pendekatan Maqashid Indeks. Jurnal Ekonomi Dan Perbankan Syariah, $3(2)$, 47-66. https://doi.org/10.46899/jeps.v3i2.160

Amaroh, S., \& Masturin, M. (2018). The Determinants of Maqasid Shariah Based Performance of Islamic Banks in Indonesia. Iqtishadia, $\quad 11(2)$, 354. https://doi.org/10.21043/iqtishadia.v11i2.3961 
Andraeny, D., \& Putri, D. D. (2017). Islamicity Financial Performance Index in Indonesian Islamic Banks. Shirkah: Journal of Economics and Business, 2(3). https://doi.org/10.22515/shirkah.v2i3.170

Antonio, M. S., Sanrego, Y. D., \& Taufiq, M. (2012). An Analysis of Islamic Banking Performance: Maqashid Index Implementation in Indonesia and Jordania. Journal of Islamic Finance, 1(1), $12-29$.

Aulia, O. D., \& Indriawati, F. (2019). Risk, Governance, Earnings, Capital (Rgec) Method And Maqashid Sharia Index (Msi): The Soundness Level Of Islamic Banks In Indonesia. ACEBISS 2019, March 26-30, Jakarta, Indonesia, March. https://doi.org/10.4108/eai.26-3-2019.2290770

Ayub, M. (2018). Maqas ${ }^{-}$. id Realisation in Islamic Finance: Components of Framework for Measurement Index. Journal of Islamic Business and Management (JIBM), November. https://doi.org/10.26501/jibm/2018.0801-001

Barry, M. A., \& Njie, M. (2020). Performance Of Conventional Banking And Islamic Banking In The Gambia: A Comparative Study Using Financial Ratio Analysis. International Journal for Research in Engineering Application \& Management (IJREAM), 06(05), 191-206. https://doi.org/10.35291/2454-9150.2020.0573

Chapra, M. U. (2007). The Islamic Vision of Development in the Light of Maqashid AlShariah.

Dusuki, A. W., \& Mokhtar, S. (2010). Critical Appraisal of Shariah Issues on Ownership in Asset-Based Sukuk As Implemented in The Islamic Debt Market. In ISRA Research Paper.

Fathurrahman, A. (2014). PENDEKATAN MAQĀṢID SYARĪ'AH : KONSTRUKSI TERHADAP PENGEMBANGAN ILMU EKONOMI DAN KEUANGAN ISLAM. Hunafa: Jurnal Studia Islamika, 11(2), 193-214. Febriadi, S. R. (2017). APLIKASI MAQASHID SYARIAH DALAM BIDANG PERBANKAN SYARIAH. Amwaluna: Jurnal Ekonomi Dan Keuangan Syariah, 1(2), 231-245.

Hajera Fatima Khan. (2017). Islamic Banking: on Its Way To Globalization. International Journal of Management Research \& Review, 7(11), 16891699.
Hartono, N. (2018). Analisis Pengaruh Islamic Corporate Governance (ICG) Dan Intellectual Capital (IC) Terhadap Maqashid Syariah Indeks (MSI) Pada Perbankan Syariah Di Indonesia. AlAmwal: Jurnal Ekonomi Dan Perbankan Syari'ah, 10(2), 259. https://doi.org/10.24235/amwal.v10i2.3249

Hasan, N. N., \& Dewi, M. K. (2019). Maqashid Shariah-Based Performance and Islamic Social Responsibility; an Empirical Study of Islamic Bank in Asean. 1st International Conference on Islamic Economics and Business (ICONIES 2018), January 2019, 410-415. https://doi.org/10.2991/iconies-18.2019.79

Hidayat, R., Oktaviani, Y., \& Aminudin, A. (2019). Financial Performance of Islamic Banking in Indonesia With Maqasid Shariah Approach. Manajemen Bisnis, 9(1), 85-97. https://doi.org/10.22219/jmb.v9i1.9442

Indonesian Ministry of National Development Planning. (2019). Indonesia Islamic Economic Masterplan 2019-2024. In Deputy of Economy Indonesian Ministry of National Development Planning (Ed.), Indonesian Ministry of National Development Planning. Indonesian Ministry of National Development Planning.

International Institute of Islamic Thought (IIIT). (2013). IBN ASHUR: Treatise on Maqashid alShari'ah. In A. S. Al-Shaikh-Ali \& S. Khan (Eds.), The International Institute of Islamic Thought

(IIIT). https://doi.org/10.2307/j.ctvkc673b

Mifrahi, M. N., \& Fakhrunnas, F. (2018). Indonesian Islamic bank's peformance under Maqāṣid Based Performance Evaluation Model (MPEM). Jurnal Ekonomi \& Keuangan Islam, 4(2), 93-103.

Mohammed, M. O., \& Razak, D. A. (2008). The Performance Measures of Islamic Banking Based on the Maqasid Framework. IIUM International Accounting Conference (INTAC IV) Held at Putra Jaya Marroitt, 25 June 2008. The Paper Won the Best Paper Award for the Conference., 1-17.

Mohammed, M. O., Tarique, K. M., \& Islam, R. (2015). Measuring the performance of Islamic banks using maqasid based model. Intellectual Discourse, 23, 401-424. 
Muchtar, E. H., \& Rofi, M. (2020). Pengukuran Kinerja Keuangan Bank Muamalat Indonesia Dengan Metode Sharia Conformity And Profit Ability (SCnP). Ekonomi Islam, 11(2), 169-186. https://doi.org/10.35891/ml.v11i2.1859

Muhammad, N., Alwi, S. F. S., \& Muhammad, N. (2020). Credit management in full-fledged Islamic bank and Islamic banking window: Towards achieving Maqasid Al-Shariah. International Journal of Financial Research, 11(3), 92-99. https://doi.org/10.5430/ijfr.v11n3p92

Mukhibad, H., Rochmatullah, M. R., Warsina, W., Rahmawati, R., \& Setiawan, D. (2020). Islamic corporate governance and performance based on maqasid sharia index- study in Indonesia. Jurnal Siasat Bisnis, 24(2), 114-126. https://doi.org/10.20885/jsb.vol24.iss2.art2

Muqorobin, A., \& Cahyo, E. N. (2019). Parameter Pengembangan Produk-Produk Perbankan Syariah Dengan Pendekatan Maqasid Syariah (Studi Kasus di Perbankan Syariah Kabupaten Ponorogo). Islamic Economics Journal, 5(2), 273. https://doi.org/10.21111/iej.v5i2.4004

Mutia, E., \& Musfirah, N. (2017). Pendekatan Maqashid Shariah Index Sebagai Pengukuran Kinerja Perbankan Syariah Di Asia Tenggara. Jurnal Akuntansi Dan Keuangan Indonesia, 14(2), 181-201. https://doi.org/10.21002/jaki.2017.10

Nasuka, M. (2017). MAQĀṢID SYARĪ'AH SEBAGAI SEBAGAI DASAR PENGEMBANGAN SISTEM, PRAKTIK, DAN PRODUK PERBANKAN SYARIAH. Jurnal Syari'ah Dan Hukum Diktum, 15(1), 1-10.

Nazreen Tabassum, C., \& Fahim, S. (2015). Shariah Governance of Islamic Banks in Malaysia. International Journal of Management Sciences and Business Research, 4(10), 115-124.

Novyanti, D., \& Roestiono, H. (2014). Pengaruh Rasio CAMEL Terhadap Tingkat Kesehatan Di Bank Tabungan Negara Syariah. Symposium of Accounting Sekolah Tinggi Ilmu Ekonomi Kesatuan, August 2014, 1-12.

Nurnazli. (2014). PENERAPAN KAIDAH MAQÂSHID SYARIAH DALAM PRODUK PERBANKAN SYARIAH. Ijtimaiyya, 7(1), 4363.
Prasetyowati, L. A., \& Handoko, L. H. (2019). Pengukuran Kinerja Bank Umum Syariah Dengan Maqasid Index Dan Sharia Conformity And Profitability (SCNP). Jurnal Akuntansi Dan Keuangan Islam, 4(2), 107-130. https://doi.org/10.35836/jakis.v4i2.22

Puspitasari, N., Rukmana, D. H., \& Sukarno, H. (2017). Analysis of Islamic Banking Efficiency Using Maqashid Shariah Approach (Study on Islamic Banks in Indonesia and Malaysia). J. Fin. Bank. Review, 2(4), 1-7. https://papers.ssrn.com/sol3/papers.cfm?abstract _id=3157591

Qoyum, A. (2018). Maqasid Ash-Shari'ah Framework and the Development of Islamic Finance Products: The Case of Indonesia. Tazkia Islamic Finance and Business Review, 12(2), 169-188. https://doi.org/10.30993/tifbr.v12i2.150

Rahman, T., Sudjana, N., \& ZA, Z. (2016). ANALISIS KINERJA PERBANKAN DENGAN PENDEKATAN RGEC (RISK PROFILE, GOOD CORPORATE GOVERNANCE, EARNING, AND CAPITAL) UNTUK MENGETAHUI TINGKAT KESEHATAN BANK (Studi pada Bank BUMN dan Bank Pembangunan Daerah Periode 20122014). Jurnal Administrasi Bisnis (JAB), 35(1), 96-103.

Ramdhoni, M. I., \& Fauzi, F. A. (2020). An Analysis of Islamic Banks Performance using Sharia Maqashid Index, Sharia Conformity and Profitability (SCnP) and CAMELS. International Journal of Applied Business Research, 2(01), 1530. https://doi.org/10.35313/ijabr.v2i01.79

Rao, P. (2018). A Review on CAMELS+(S): (S) Shariah Rating For- Islamic Banks. The International Journal Research Publication's Research Journal of Economics \& Business Studies, $\quad$ 07(2251 1555), 68-73. https://www.researchgate.net/publication/32497 6372

Rashidah, A. R., \& Faisal, D. (2015). Maqasid AlShari'ah-based performance measurement for Halal industry. Humanomics, 31(3), 354-371.

Rusydiana, A., Marlina, L., \& S. Rahayu, S. (2019). Efficiency, Productivity and Stability of Islamic Banks in Indonesia. Proceedings Ofthe 4th Sriwijaya Economics, Accounting, and Business Conference (SEABC 2018), December, 566-572. https://doi.org/10.5220/0008442605660572 
Jurnal Ilmiah Ekonomi Islam, 7(01), 2021, 385

Rusydiana, A. S., Tanjung, H., \& Marlina, L. (2018). Maslahah Based Measurement on Indonesia Islamic Banks. International Journal of Islamic Business $\quad$ Ethics, 3(1), 365. https://doi.org/10.30659/ijibe.3.1.365-382

Toriquddin, M. (2013). TEORI MAQASHID SYARI'AH PERSPEKTIF IBNU ASHUR. Ulul Albab, 14(2), 1-19. https://doi.org/10.18860/ua.v14i2.2657

Wahid, N. N., Firmansyah, I., \& Fadillah, A. R. (2018). Analisis Kinerja Bank Syariah Dengan Maqashid Syariah Index (MSI) Dan Profitabilitas. Jurnal Akuntansi, 13(1), 1-9.
Wahyuni, S., Pujiharto, P., \& Hartikasari, A. I. (2020). Sharia Maqashid Index and Its Effect on The Value of The Firm of Islamic Commercial Bank in Indonesia. Riset Akuntansi Dan Keuangan Indonesia, $\quad 5(1), \quad 36-45$. https://doi.org/10.23917/reaksi.v5i1.9493

Wasyith, W. (2017). Beyond Banking: Revitalisasi Maqāṣid dalam Perbankan Syariah. Economica: Jurnal Ekonomi Islam, 8(1), 1. https://doi.org/10.21580/economica.2017.8.1.18 23 